\title{
Schistosomiasis Control Based on Repeated Chemotherapy in a Rural Village of the Sugar-Cane Zone in Northeast Brazil
}

\author{
Otávio S Pieri/ ${ }^{+}$, Constança S Barbosa*, Patrícia G Moza
}

\author{
Departamento de Biologia, Instituto Oswaldo Cruz, Av. Brasil 4365, 21045-900 Rio de Janeiro, RJ, Brasil \\ *Departamento de Parasitologia, Aggeu Magalhães, Centro de Pesquisas-Fiocruz, Av. Moraes Rego s/n, \\ 52020-020 Recife, PE, Brasil
}

A schedule of repeated chemotherapy with oxamniquine, consisting of biannual treatment of schoolaged (7-13 years) children and annual treatment of all other age groups, was used in a representative rural village from a highly endemic area of schistosomiasis in Pernambuco. Significant reductions in infection were obtained only after two cycles of treatment, as the overall prevalence decreased from $72.6 \%$ to $41.7 \%$ and the geometric mean egg counts per gram of faeces among positives fell from 188.4 to 76 . In a school-aged cohort $(n=29)$ three treatments at six-month intervals were necessary to significantly reduce the proportion of positives (from $75.9 \%$ to $51.7 \%$ ). In a cohort of children under 7 years of age $(n=20)$ the proportion of positives actually increased (from 30\% to 45\%) despite two annual treatments. Water contact was intense and host snail density was relatively high. As there is no shortterm perspective of improved sanitation, auxiliary measures such as focal mollusciciding are needed for an adequate control of schistosomiasis in this and alike areas.

Key words: schistosomiasis - control - chemotherapy - epidemiology

Recent accounts of the schistosomiais control programme, carried out in Brazil by the Fundação Nacional de Saúde (FNS), indicate that prevalence is rising in some areas of northeast Brazil (WHO 1993, Amaral \& Porto 1994). In the sugar-cane zone of Pernambuco, a highly endemic area of schistosomiasis, drug treatment was administered four times (at 2-3 year intervals) between 1978 and 1986, reducing prevalence by $10.7 \%$ (from $35.1 \%$ to $24.4 \%$ ). Between 1987 and 1990, overall prevalence in the State of Pernambuco increased alarmingly from $9.9 \%$ to $25.6 \%$ (Rey 1992).

Failure of this chemotherapy-based programme to control disease transmission in these areas may be due to the following aspects: (i) the interval between drug treatments has been excessively long, which would not prevent reinfection; (ii) little attention has been given to school-aged children, who should be the major target for chemotherapy. Thus, it can be hipothesized that a higher frequency of treatments,

\footnotetext{
This investigation received financial support from the UNDP/World Bank/WHO Special Programme for Research and Training in Tropical Diseases and from CNPq. ${ }^{+}$Corresponding author. Fax: +55-21-290.1146. E-mail: opieri@infolink.com.br

Received 4 May 1998

Accepted 31 August 1998
}

specially among school-aged children, is required to reduce prevalence to acceptable levels.

To verify the above hypothesis, a small rural village, namely Bela Rosa ( $35^{\circ} 07^{\prime} 10^{\prime \prime} \mathrm{W}, 8^{\circ} 00^{\prime} 20^{\prime \prime}$ $S$ ), was chosen in the municipality of São Lourenço da Mata, sugar-cane zone of Pernam-buco. This village has been well studied epidemiologically since 1967 (Barbosa et al. 1970, Barbosa \& Costa 1981, Barbosa \& Silva 1992, 1996) as a representative rural community in the sugar-cane area of Pernambuco. Between 1980 and 1989 prevalence increased from $21.5 \%$ to $92 \%$ in the village, despite selective drug treatments being administered by the FNS in 1981, 1984 and 1986. For the present study, a schedule of repeated chemotherapy was introduced in Bela Rosa from 1990 to 1992 , consisting of bi-annual treatments of infected school-aged children and annual treatments of infected individuals of all other agegroups. Changes in infection parameters at sucessive stool surveys were then compared between treatments, aiming to evaluate the impact of the schedule used.

\section{MATERIALS AND METHODS}

Preliminary survey - All waterbodies in and around the village were surveyed and examined in September 1990 for the presence of Biomphalaria straminea, the only snail host species in the area. Main water-courses, paths and water-contact sites were depicted in a sketch map of the village. The 
study village was then surveyed house-to-house. Visitors informed the residents of the purpose of the project, and briefly described the treatment schedule as well as the prospective benefits. School children and teachers were also made aware of the project activities. A questionnaire was applied to the heads of families to obtain personal data of residents, as well as to record the sanitary standards of the houses. The following epidemiological variables were considered: faeces disposal - categorized as either adequate (in latrines, burrowing, burning) or inadequate (open air, near or in the water); water supply - either safe (treated, piped water) or unsafe (stream water); water contact - either high (bathing, swimming, playing, laundering) or low (collecting water, dish-washing, fishing, fording).

Snail monitoring - Snail-host habitats identified as water-contact sites were chosen for monitoring. Sampling stations were demarcated and surveyed periodically (at three-month intervals for one year and monthly thereafter) by the Olivier and Schneiderman (1956) method.

Stool surveys and chemotherapy - The first stool examination of the total population was made in December 1990. Stool containers were left at each house for collection in the following days and then examined by the Kato-Katz method (Katz et al. 1972), two slides being used for each sample. Patients found positive for Schistosoma mansoni were visited in their houses and medicated, except those reporting liver disease, epilepsy or pregnancy. Patients were given a single dose of oral oxamniquine as prescribed by FNS (Table I). The medicated patients were advised of possible sideeffects and asked to report any discomfort or illness within the following $24 \mathrm{hr}$. A stool survey was carried out in March 1991 among the treated persons to detect non-cured cases. Those still found positive for $S$. mansoni were medicated again. All children ranging from 7-13 years of age were further surveyed in June 1991 and treated if positive. A second cycle of stool examinations and drug treatments was repeated between December 1991 and June 1992. In December 1992 a final stool survey of the total population was made, followed by medication of the positive cases.

Data elaboration and analysis - Relative abundance of $B$. straminea at each survey was given by the number of snails collected per person per minute per sampling station. The amount of oxamniquine per body weight given to patients according to FNS's prescription was calculated for the following age ranges: $0-13,14-19$ and 20-79 years. The following parameters of human infection were based on egg counts obtained from the stool surveys: prevalence of infection (percentage of individuals with S. mansoni eggs in their faeces at a given survey); prevalence of moderate to heavy infections (percentage of individuals with at least 100 eggs per gram of faeces at a given survey), intensity of infection (geometric mean of the number of eggs per gram of faeces among egg-positive individuals at a given survey), egg-negative rate (percentage of egg-positive individuals who have been treated and are egg-negative at a follow-up examination); reinfection rate (percentage of eggnegative individuals at least three months after medication, but who are again positive after six months or more). Statistical analysis of the data were carried ou through the SYSTAT-5 package (Wilkinson 1990). Association between rainfall and relative abundance of $B$. straminea was evaluated through Spearmann's coefficient of correlation. Diferences in prevalence and intensity of infection in the total population before and after treatment were statistically evaluated through Wilcoxon test on eight pairs matched by age range, as follows: 0$6,7-13,14-19,20-29,30-39,40-49,50-59$ and 6079 years. Changes in infection after treatment and re-treatment were monitored in a follow-up group from the following age ranges: $0-6,7-13,14-19,20$ 39 and $40-79$ years. The group was formed by all fully compliant residents who remained in the age range of the initial survey. Significance of differences in the individual infection status, either positive or negative, within each age range of the follow-up group was evaluated by the Sign test.

\section{RESULTS}

The preliminary survey identified 86 households and 355 residents, $40.5 \%$ of whom were under 12 years of age. Time of residence in the village was five years or more in $79.1 \%$ of the families. Illiteracy prevailed among $59.9 \%$ of the patients over 11 years old. The working force was mainly in sugar-cane cutting. Only $29.2 \%$ of the residents were regularly employed by the sugar estate that owned the land; monthly earnings being less than two minimum wages. Faeces disposal was categorized as inadequate in $72.4 \%$ of the cases reported. There was no safe water supply in the village. The nearby streams (Fig. 1) were used for all water-related activities. In $61 \%$ of the reported cases the water contact was considered high, as it involved bathing, swimming, playing or laundering in the streams.

Eleven water-contact sites were identified in the area and chosen as sampling stations for snail monitoring (Fig. 1). Relative abundance of $B$. straminea varied seasonally, reaching the highest level in December, when rainfall was lowest (Fig. 2). A negative correlation was detected between snail counts and rainfall (Spearman's coefficient $=$ $-0.54 ; \mathrm{n}=29 ; \mathrm{P}<0.05)$. 


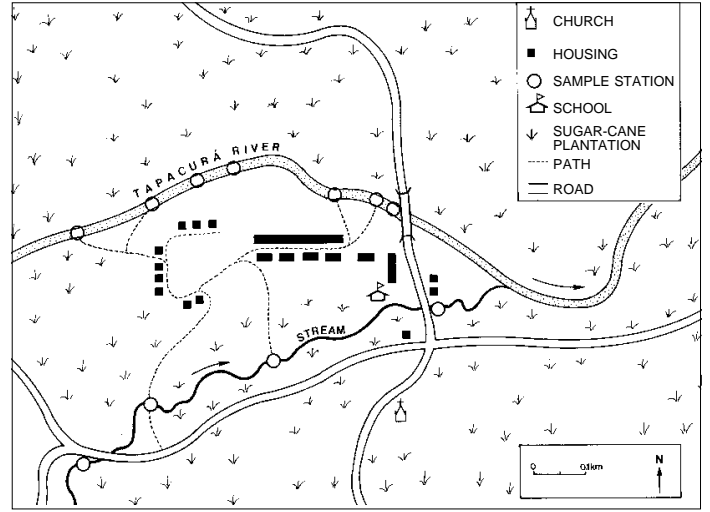

Fig. 1: sketch map of Bela Rosa village ( $35^{\circ} 07^{\prime} 10^{\prime \prime} \mathrm{W}, 8^{\circ} 00^{\prime}$ $\left.20^{\prime \prime} \mathrm{S}\right)$ showing the location of main water-courses and watercontact sites (sampling stations) in relation to roads, footpaths and housing in September 1990

\section{TABLE I}

Administration of oxamniquine (Mansilò) according to body weight as prescribed by the National Health Foundation in schistosomiasis control campaigns. One capsule or $5 \mathrm{cml}$ of syrup contains $250 \mathrm{mg}$ of oxamniquine

\begin{tabular}{ccc}
\hline Body weight $(\mathrm{kg})$ & No. of capsules & $\begin{array}{c}\text { Amount of } \\
\text { syrup (ml) }\end{array}$ \\
\hline $5-6$ & - & 2 \\
$7-8$ & - & 3 \\
$9-11$ & - & 4 \\
$12-13$ & - & 5 \\
$14-16$ & - & 6 \\
$17-18$ & - & 7 \\
$19-21$ & - & 8 \\
$22-23$ & - & 9 \\
$24-40$ & 2 & - \\
$41-60$ & 3 & - \\
over 60 & 4 & - \\
\hline
\end{tabular}

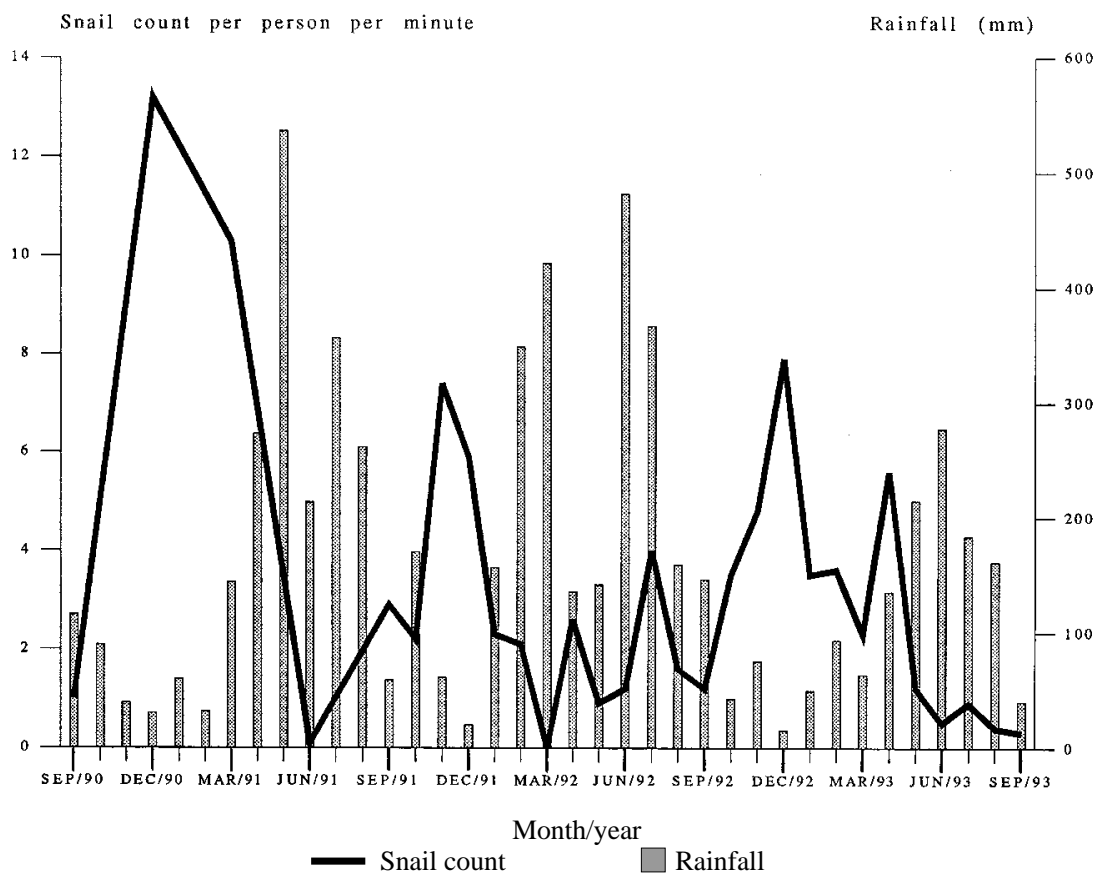

Fig. 2: average counts per person per minute of Biomphalaria straminea snails from 11 sampling sites in Bela Rosa village in relation to monthly rainfall. Snail surveys were made at three-month intervals for one year and monthly thereafter. Rainfall data are from Recife ( $\left.34^{\circ} 55^{\prime} 00^{\prime \prime} \mathrm{W}, 8^{\circ} 04^{\prime} 03^{\prime \prime} \mathrm{S}\right)$.

Following prescription by FNS (Table I), children under 14 years of age were given $19.4 \pm 2.52$ (mean and standard deviation) $\mathrm{mg}$ of oxamniquine per kg of body weight, whereas those between 14 and 19 years received $15.1 \pm 2.31 \mathrm{mg} / \mathrm{kg}$; the adults (20 years or more) were given $14.3 \pm 1.42 \mathrm{mg} / \mathrm{kg}$. Less than $20 \%$ of the persons eligible for examination failed to provide stool samples at the various surveys, and compliance with chemotherapy exceeded $85 \%$ in all but the first survey (Table II). Overall prevalence of infection decreased by $7.9 \%$ after the first cycle of treatment and by $30.9 \%$ after the second one (Table III). Matching prevalences by age range revealed significant differences ( $\mathrm{p}<0.05$ ) between 1990 and 1992, as well as 1991 and 1992. No significant difference in overall prevalence was found between 1990 and 1991 ( $\mathrm{p}>0.05)$. 
Overall geometric mean of positive egg loads fell $12.7 \%$ after the first cycle of treatment and $59.7 \%$ after the second one, whereas overall prevalences of moderate to heavy infection decreased by $9.8 \%$ and $32.2 \%$, respectively (Table
IV). Significant reductions $(\mathrm{p}<0.05)$ in both egg load and moderate to heavy infections were found between 1990 and 1992, as well as 1991 and 1992. No significant difference in these indices were detected between 1990 and 1991 ( $p>0.05)$.

\section{TABLE II}

Numbers of eligible persons, exams, egg-positive persons and treatments at sussessive stool surveys in Bela Rosa. Percentages of persons examined and treated are given in parenthesis. The persons eligible for examination were as follows: December: all residents; March: all egg-positives in the previous December; June: all school-aged children ( $7-13$ years)

\begin{tabular}{lcccc}
\hline Survey (month/year) & No. of eligible persons & No. examined & No. of egg-positives & No. treated \\
\hline December/1990 & 355 & $288(81.1)$ & 209 & $160(76.6)$ \\
March/1991 & 209 & $178(84.8)$ & 75 & $64(85.3)$ \\
June/1991 & 90 & $80(88.9)$ & 66 & $66(100.0)$ \\
December/1991 & 413 & $334(80.9)$ & 223 & $210(97.2)$ \\
March/1992 & 223 & $190(85.2)$ & 61 & $56(91.8)$ \\
June/1992 & 119 & $111(93.3)$ & 56 & $52(92.9)$ \\
December/1992 & 472 & $439(93.0)$ & 183 & $173(94.5)$ \\
\hline
\end{tabular}

TABLE III

Prevalence of infection by Schistosoma mansoni in relation to age in Bela Rosa before and after each cycle of drug treatement. The percentages of egg-positive individuals are given in parenthesis

\begin{tabular}{ccccccccc}
\hline & \multicolumn{2}{c}{$\begin{array}{c}\text { Before treatment } \\
\text { (December 1990) }\end{array}$} & & \multicolumn{2}{c}{$\begin{array}{c}\text { After the 1st cycle of treatment } \\
\text { (December 1991) }\end{array}$} & & $\begin{array}{c}\text { After the 2nd cycle of treatment } \\
\text { (December 1992) }\end{array}$ \\
\cline { 2 - 3 } \cline { 7 - 8 } Age (years) & No. examined & No. of positives & & No. examined & No. of positives & & No. examined & No. of positives \\
\hline $0-6$ & 59 & $26(44.1)$ & & 66 & $38(57.6)$ & & 89 & $31(34.8)$ \\
$7-13$ & 78 & $60(76.9)$ & & 96 & $80(83.3)$ & & 111 & $56(50.5)$ \\
$14-19$ & 45 & $40(88.9)$ & & 45 & $30(66.7)$ & & 72 & $37(51.4)$ \\
$20-29$ & 21 & $18(85.7)$ & & 27 & $21(77.8)$ & & 53 & $24(45.3)$ \\
$30-39$ & 26 & $25(96.2)$ & & 28 & $14(50.0)$ & & 37 & $15(40.5)$ \\
$40-49$ & 29 & $24(82.9)$ & & 29 & $14(48.3)$ & & 27 & $7(25.9)$ \\
$50-59$ & 13 & $7(53.8)$ & & 19 & $10(52.6)$ & & 25 & $6(24.0)$ \\
$60-79$ & 17 & $9(52.9)$ & & 24 & $9(37.5)$ & & 25 & $7(28.0)$ \\
\hline All ages & 288 & $209(72.6)$ & 334 & $216(64.7)$ & & 439 & $183(41.7)$ \\
\hline
\end{tabular}

\section{TABLE IV}

Intensity of infection by Schistosoma mansoni in relation to age in Bela Rosa before and after each cycle of drug treatment. The following indices are given: geometric mean of the number of eggs per gram of faeces (epg) among positive cases and prevalence of moderate to heavy infection (percentage of individuals with more than $100 \mathrm{epg}$ )

\begin{tabular}{|c|c|c|c|c|c|c|}
\hline \multirow[b]{2}{*}{ Age (years) } & \multicolumn{2}{|c|}{$\begin{array}{l}\text { Before treatment } \\
\text { (December 1990) }\end{array}$} & \multicolumn{2}{|c|}{$\begin{array}{l}\text { After the 1st cycle of treatment } \\
\text { (December 1991) }\end{array}$} & \multicolumn{2}{|c|}{$\begin{array}{l}\text { After the 2nd cycle of treatment } \\
\text { (December 1992) }\end{array}$} \\
\hline & $\begin{array}{l}\text { Geometric } \\
\text { mean epg }\end{array}$ & $\begin{array}{l}\% \text { of individuals } \\
\text { with epg }>100\end{array}$ & $\begin{array}{r}\text { Geometric } \\
\text { mean epg }\end{array}$ & $\begin{array}{l}\% \text { of individuals } \\
\text { with epg }>100\end{array}$ & $\begin{array}{l}\text { Geometric } \\
\text { mean epg }\end{array}$ & $\begin{array}{c}\% \text { of individuals } \\
\text { with epg }>100\end{array}$ \\
\hline $0-6$ & 129.4 & 23.7 & 96.4 & 27.3 & 55.5 & 12.4 \\
\hline $7-13$ & 304.8 & 60.3 & 272.3 & 59.4 & 75.5 & 19.8 \\
\hline $14-19$ & 317.0 & 73.3 & 191.4 & 44.4 & 105.7 & 23.6 \\
\hline $20-29$ & 107.6 & 47.6 & 187.5 & 55.5 & 82.6 & 24.5 \\
\hline $30-39$ & 154.5 & 53.8 & 96.6 & 17.9 & 90.6 & 18.9 \\
\hline $40-49$ & 117.5 & 57.7 & 66.5 & 17.2 & 59.0 & 7.4 \\
\hline $50-59$ & 128.5 & 46.2 & 164.8 & 36.8 & 77.4 & 8.0 \\
\hline $60-79$ & 54.2 & 17.6 & 74.6 & 16.7 & 37.8 & 4.0 \\
\hline All ages & 188.4 & 49.3 & 164.4 & 39.5 & 76.0 & 17.1 \\
\hline
\end{tabular}


In the follow-up group (Table V) prevalence of infection increased significantly between 1990 and 1991 among children under 7 years, did not differ significanlty in the 7-13 years range, and decreased significantly in the age ranges over 13 years. Prevalence of moderate to heavy infections did not differ significantly between 1990 and 1991 in the age ranges under 14 years, and decreased significantly in the other age ranges. Between 1990 and 1992, both prevalence of infection and prevalence of moderate to heavy infections decreased significantly in all age ranges but $0-6$ years.

Only 72 persons moved out the village between January 1991 and December 1992. However, 189 persons moved in during that period. Of these, 164 were examined within one year of arrival, 93 (56.7\%) being found positive.

By March 1993 the land owners reclaimed the area for cattle ranching, indemnified the villagers and demolished the houses.

\section{DISCUSSION}

The cross-populational results (Tables III, IV) show that the present schedule of repeated chemotherapy only had significant impact on infection after two cycles of treatment. This failure in reducing prevalence and intensity of infection to acceptable levels is not surprising, as water-contact patterns were intense, and snails occurred mostly at high densities. The particularly poor results obtained after the first cycle of treatment may be also due to a relatively low rate of participation in December 1990. In fact, the population only became satisfactorily cooperative from the following year onwards, when absences and refusals were reduced to a minimum (Table II). It is also possible that infected newcomers have contributed to keep prevalence high, as they were only identified and treated at survey times.

The results from the follow-up group (Table V) show that the cohorts over 13 years of age needed only one cycle of treatment to significantly change the individual infection status from positive to negative. However, the 7-13 years-old cohort needed three medications at six-month intervals before the proportion of positives was significantly reduced. As the moderate to heavy infections were significantly reduced after only one medication, it is likely that the initial impact of chemotherapy in this cohort was mainly on the egg load, and subsequent treatments were necessary to promote negativation. Low negativation rates in children associated with high initial levels of heavy infections were also reported by Polderman et al. (1988) and Gryseels (1990).

Another vulnerable group in the present study area were the children under 7 years of age, as prevalence remained above the pre-control level

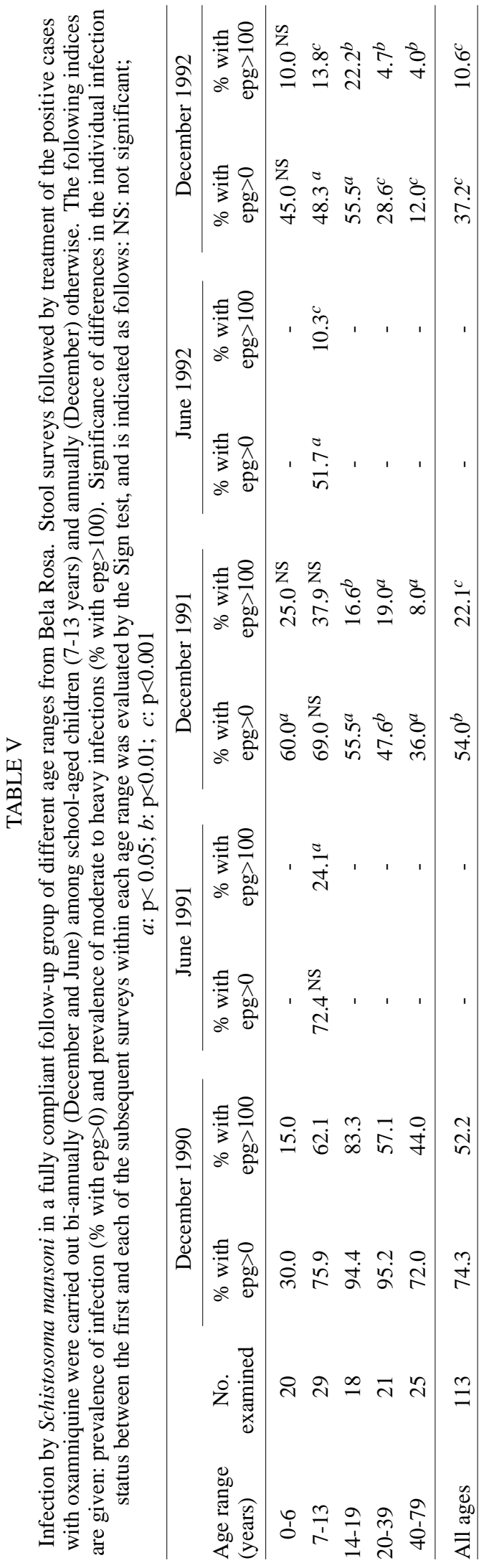


even after two cycles of treatment. This may be due both to low resistance to reinfection (Gryseels 1994) and to increased water contact (Zhongdao et al. 1994).

In contrast with the findings from other endemic areas (Sleigh et al. 1981, Barakat et al. 1995, Homeida et al. 1996), it is unlikely that repeated chemotherapy alone would keep infection down at satisfactory levels among children in the present study area. Since continuing cycles of bi-annual treatment would be unfeasible, the best strategy here might be to combine targeted chemotherapy with other measures, such as small-scale environmental interventions (Kloetzel et al. 1994, Pieri 1995) and focal mollusciciding (Sturrock 1995).

\section{AKNOWLEDGEMENTS}

To Dr Ubiracy Guida, from the Fundação Nacional de Saúde, Recife, for assistance with chemotherapy; to Dr André Furtado for providing facilities at IAMFiocruz, Recife, and to the staff of the Estação de Biologia Experimental de São Lourenço da Mata for technical suport.

\section{REFERENCES}

Amaral RS, Porto MAS 1994. Evolução e situação atual do controle da esquistossomose no Brasil. Rev Soc Bras Med Trop 27 (Suppl III): 73-90.

Barakat R, El Masry AG, Farghaly A, El Morshidy HN, El Sayed MK, Husein MH, Miller FD 1995. Impact of population-based selective chemotherapy on prevalence and intensity of Schistossoma mansoni infections in the Nile Delta: Kafr El Sheikh. Trop Geogr Med 47: 266-270.

Barbosa CS, Silva CB 1992. Epidemiologia da Esquistossomose Mansônica no engenho Bela Rosa, Município de São Lourenço da Mata, Pernambuco, Brasil. Cad Saúde Públ 8: 83-87.

Barbosa CS, Silva CB, Barbosa FS 1996. Esquistossomose: reprodução e expansão da endemia no Estado de Pernambuco, Brasil. Rev Saúde Públ 30: 609-616.

Barbosa FS, Costa DPP 1981. A long term schistosomiasis control project with moluscicide in a rural area of Brazil. Ann Trop Med Parasitol 75: 41-52.

Barbosa FS, Pessoa D, Pinto RF, Barbosa JM, Rodrigues BA 1970. Levantamento seccionais sobre a esquistossomose no nordeste do Brasil. III Estado de Pernambuco (Município de São Lourenço da Mata). Rev Soc Bras Med Trop 5: 269- 280.

Katz N, Chaves A, Pellegrino J 1972. A simple device for quantitative stool thick-smear technique in schistosomiasis mansoni. Rev Inst Med Trop São Paulo 14: 397- 400.

Kloetzel K, Chieffi PP, Carrilho FJ 1994. Environmental intervention as a tool for control of schistosomiasis. Suggestions from a field study in Northeast Brazil. Cad Saúde Públ 10: 337-344.

Gryseels B 1990. Impact of repeated selective chemotherapy on infection and morbidity rates in schistosomiasis mansoni in Burundi, p. 136-216. In B Gryssels, Morbidity and Morbidity Control of Schistosomiasis Mansoni in Subsaharan Africa, Proefschrift, Leiden.

Gryseels B 1994. Human resistance to Schistosoma infections: age or experience? Parasitol Today 10: 380384.

Homeida MMA, Eltoum IA, Ali MM, Suliaman SM, Elobied EA, Mansour M, Saad AM, Bennett JL 1996. The effectiveness of annual versus biennial mass chemotherapy in reducing morbidity due to schistosomiasis: a prospective study in Gezira-Managil, Sudan. Am J Trop Med Hyg 54: 140-145.

Olivier LJ, Scheinderman M 1956. A method for estimating the density of aquatic snail population. Exp. Parasitol 5: 109-117.

Pieri OS 1995. Perspectivas no controle ambiental dos moluscos vetores da esquistossomose, p. 239-252. In FS Barbosa, Tópicos em Malacologia Médica, Editora Fiocruz, Rio de Janeiro.

Poldermam AM, Gryseels B, De Calunce P 1988. Cure rates and egg reduction in treatment of intestinal schistosomiasis with oxamniquine and praziquantel in Maniema, Zaire. Trans $R$ Soc of Trop Med Hyg 82: 115-116.

Rey L 1992. Bases da Parasitologia Médica, Editora Guanabara-Koogan, Rio de Janeiro, 349 pp.

Sleigh AC, Mott KE, França Silva JT, Muniz TM, Mota EA, Barreto ML, Hoff R, Maguire JH, Lehman JS, Sherlock J 1981. A three year follow-up of chemotherapy with oxamniquine in a Brazilian community with endemic schistosomiasis mansoni. Trans $R$ Soc Trop Med Hyg 75: 234-238.

Sturrock RF 1995. Current concepts of snail control. Mem Inst Oswaldo Cruz 90: 241-248.

Wilkinson L 1990. SYSTAT: the system for statistics, SYSTAT Inc., Evanston, xviii $+677 \mathrm{pp}$.

WHO 1993. The Control of Schistosomiasis, World Health Organization Technical Report Series, 830.

Zhongdao W, Zhang S, Binrong P, Lingshang $\mathrm{H}$, Renming W, Zulu G, Jianying L, Brinkmann U 1994. Reinfection with Schistosoma japonicum after treatment with praziquantel in Poyang lake region, China. S Asian J Trop Med Publ Hlth 25: 163-169. 